\title{
Mobile Technologies - Information on the Move ... or Stuck in a Groove? - A South African Perspective ${ }^{1}$ by \\ Denise Rosemary Nicholson \\ University of the Witwatersrand, Johannesburg \\ Denise.Nicholson@wits.ac.za
}

\begin{abstract}
:
Mobile technologies present exciting and new opportunities to those who have not been able to access digital information before or provide additional opportunities for access. Education programmes and curricula are being revitalized through innovative technologies. Digital technology has the potential to revolutionize the lives of people with sensory-disabilities. Developing countries are now able to tap into global knowledge through a variety of hand-held devices. There is a lot of information available on open access which can be downloaded to these technologies. However, not everything is free. Copyright issues have to be taken into account when using copyrighted material on these devices. Rights-holders and manufacturers control use and access to information on mobile devices through the use of digital rights management systems (DRMs), technological protection mechanisms (TPMs), and strict licences. This paper highlights some benefits of mobile technology for education and disseminating information in a developing country's context. It also discusses how copyright, licensing and technological protection measures prevent or hamper access and help to keep information 'stuck in a groove'.
\end{abstract}

\section{Introduction}

There is a huge knowledge and digital divide between developed countries and developing countries, particularly in Africa. African countries depend heavily on educational, recreational and other published material from industrialized countries. They are net importers of intellectual property and pay huge amounts to purchase or gain access to global information and knowledge. In the process, researchers and tertiary institutions very often have to buy back their own African research that is published in subscription-based journals with no open access options.

As technology develops, African countries need to find better ways of accessing information to gain knowledge and be able to participate and contribute to the global society. They need technology to assist them in developing at a faster rate so that they can advance and one day, enjoy the status of developed nations. Africa is the second-largest and second most-populous continent after Asia, yet its internet usage is only 5.7 percent compared to other largely populated areas of the world (Internet Users, 2011).

\footnotetext{
${ }^{1}$ This is an adapted version of the author's paper presented on 13 May 2011, at the Third International Conference M-Libraries Conference, held in Brisbane, Australia (11-13 May 2011.
} 


\section{The Knowledge and Digital Divide}

According to the Global Information Technology Report 2010/11, Sub-Saharan Africa still lags behind the rest of the world. The main issues are underdeveloped infrastructure, inefficient markets, opaque regulatory environments, inadequate educational standards, and widespread poverty. These are powerful obstacles against a more extensive and efficient use of new technologies for increased development and prosperity in the region (World Economic Forum, 2011). "This means that mobile technologies serve to both address and to complicate our notions of the 'digital divide,' the gulf between the Internet technology haves and have-nots" (Watters, 2011, paragraph 4). Since most Africans will never own a laptop, Kindle or iPad, the mobile phone is key to sustained 'information on the move' ${ }^{, 2}$ in Africa.

On one hand, mobile phones will increasingly serve as both our gateway to the Internet and as our personal computers. As costs decrease, more people will own or have access to mobile computing devices. However, accessibility and equity remain an issue. Income still dictates cell phone ownership and Internet access. Poorer communities may only be able to afford (if at all) the less sophisticated cellular models without Internet access, instant messaging and other features, whilst people who are better off economically can afford models which offer a whole range of applications (Smart phones and various Blackberry models for example). For many people, accessing the Internet via their phone is their only connection as they do not have Internet at home due to the costs and/or lack of electricity or reasonable bandwidth (Watters, 2011).

Cell phone batteries need to be regularly charged, and this hampers uninterrupted use of mobile phones at this stage. Users in many rural areas have to take regular trips into nearby towns that have electricity to charge their batteries. However, as solar energy is harnessed for better power options in Africa, this problem may disappear in time.

\section{Emergence from 'Darkest Africa' ${ }^{3}$ - 'Information on the Move'}

Africa is often characterized as the 'dark' or 'silent continent' "because her abundance of knowledge, research and practice does not reach far beyond its local audience" (Gray, 2010). For years, lack of bandwidth and extremely slow satellite connections have "arrested development on the African continent and have constrained Africa from achieving her full potential" (Okine, 2011, para. 8). Information and communications technology "[ICT] and collaborative communication are now offering new possibilities for giving Africa a voice across the globe" (Gray, 2010). Since 2009, the capacity of Africa's fibre optic cable connections has expanded almost 300-fold. The SEACOM fibre optic cable system was launched to support East

\footnotetext{
${ }^{2}$ Information accessible via mobile technologies

${ }^{3}$ http://njisworld.wordpress.com/mr-duells-articles/the-dark-continent-european-colonization-in-africa/
} 
and Southern African countries with inexpensive bandwidth, thus removing the international infrastructure bottleneck. On 20 April, 2011, the 14,000 kilometre West Africa Cable System (WACS) fibre optic line arrived in South Africa's Western Cape Province. The cable starts in London and will connect fifteen points along Africa's western coast. This will link the continent's Internet providers directly to the servers of Europe and boost the bandwidth of the world's least connected region. The new link is the latest in a series of submarine cables that hold the promise of an Internet explosion for Africa (Massive undersea cable, 2011). It will most certainly speed up 'information on the move' for Africa.

\section{Africa as the First post-PC Continent?}

Digital and particularly, mobile technology, provides huge potential for research, learning and teaching purposes. A convergence of historical circumstance and an increase in innovative mobile applications may make Africa the first post-PC continent, because the majority of Africans do not have the luxury of laptops, iPads, Kindles and the like (Wanjiku, 2011). They will embrace mobile applications, like cell phones to engage the digital world. The mobile phone will become the main or default mode of 'information on the move' for millions on the continent. Cell phones will be the means whereby Africans engage in communication, teaching and learning, civic, political and social activities, e-banking and other financial services.

\section{Mobile Technologies - Advantages for Africa}

African countries are already starting to benefit from the use of digital devices, such as mobile phones, Smart phones, Blackberries, as well as iPods, e-books and digital game consoles. Few people are able to afford the iPad at this stage. A number of non-profit organizations are using mobile networks to deliver mobile health services, such as patient data collection and the dissemination of health information, to poor, rural populations throughout Africa (World Economic Forum, 2011).

Farming communities are using mobiles to share important information on agricultural and related information in rural areas. Conservationists are using mobile phones in their endeavours to protect wildlife from poaching and other dangers.

Educators are realizing the untapped potential of personal technologies and how they can change learning in the classroom and beyond its walls. Tertiary institutions are embracing e-learning and m-learning (mobile learning) in imaginative ways. Distance learners are now able to seek help from lecturers, engage in online study groups, and discussions. Non-profits and operators can also collaborate to offer formal and informal lessons, useful information, study tips, tutorials and quizzes via mobiles (World Economic Forum, 2011).

Mobile devices have been used to crowdsource information, for example, in times of political change in African countries such as Tunisia, Egypt, Cote d'Ivoire, Sudan and Libya, during 2011. They have also been used to communicate, share information and provide assistance to 
communities ravished by earthquakes and tsunamis, such as Haiti, New Zealand and Japan. Mobiles have also changed the way in which civil society organizations and protest groups organize their activities (Mobile phones and development, n.d.).

Many commercial entities already provide information via mobile phones on direct marketing, economic information, advertisements, life insurance policy options, competitions and a great deal more. Airlines provide services for bookings and check-ins on mobile phones. Radio stations provide online information about traffic congestion, news, weather reports, communitybased activities, social upliftment and development programmes and other useful information.

Libraries are incorporating mobile technology into their services, for example, online access to their catalogues via mobile phones; Short Message Service (sms) alerts about outstanding loans, new acquisitions, information literacy training, changes in opening hours, workshops and other services.

Electronic voting is being piloted in a number of African countries, e.g. Kenya, Ghana and Nigeria, but a lot more has to be done before this becomes a continental voting process. There are cultural issues as well as concerns about privacy, security and anonymity since some countries now require subscribers to register their Subscriber Identity Module (SIM) cards, and there is concern on the part of citizen that their votes may be tracked. "The process must enhance democracy not build or entrench a digital divide. The system must be usable by the young and the old, the rural and the urban, the physically challenged and the able and finally the literate and the illiterate voter" (E-Voting in Africa: Mr. Collin Thakur., 2010, p. 27). It is an inevitable process for Africa as it advances technologically, but more work has to be done to 'fine tune' the process, before any country will embrace it fully.

Lack of communication can be a major barrier for grassroots non-governmental organizations working in developing countries. FrontlineSMS is the first text messaging system created exclusively with this problem in mind. By leveraging basic tools already available to most nongovernment organisations (NGO's) - computers and mobile phones - FrontlineSMS enables instantaneous two-way communication on a large scale. The software is free and it is easy to implement and operate. Messages are paid for in the normal way (FrontlineSMS, n.d.).

Mobile phones provide increased access to entertainment, both traditional formats (such as radio and recorded music) and new forms such as online gaming and access to online video sites, like YouTube (Mobile phones and development, n.d.).

The marriage of mobile phones and community radio is a natural one. They both facilitate "anywhere, anytime learning", but in different, complementary ways. Learning programmes can use phones to interact with learners - register them, provide learner support and assessing learning outcomes - overcoming barriers faced by radio and other traditional media. Learners can access educational content as and when they need it. Radio, on the other hand, provides for an engaging and collective learning environment that can reach large numbers with a single broadcast at a low cost. Together, mobiles and radio can increase the degree of participation in

Pg. 4 
learning for development, which is key. Communities must be active participants in community learning - by shaping priorities, sharing experiences and providing ongoing input (Pringle, 2011, para.1).

Two innovative mobile applications that can act as a complement to radio, are Freedom Fone (developed in Zimbabwe) and Gramin Radio Inter-Networking System (GRINS) developed by the Indian Institute of Technology in Delhi, for use by community radio stations (Pringle, 2011).

\section{Mobile Revolution in South Africa}

The World Wide Worx Mobility 2011 research report reveals that 39 percent of urban South Africans and 27 percent of rural users are now browsing the Internet on their mobile phones. The study excludes "deep rural" users, and represents around 20-million South Africans aged 16 and above. This means that at least 6 million South Africans now have Internet access on their phones (World Wide Worx, 2010).

The most popular in terms of mobile sites and services is MXit, an instant messaging service, developed in South Africa, which currently has "close to 40 million thumbs twiddling in more than 120 countries, with 40000 new subscribers every day" (The Master of IM, n.d., para. 6). It is the largest social network in Africa (At 27 Million, 2010). The breakdown of users is as follows: 24 percent of cell phone users aged 16 and above (29 percent of urban, 19 percent of rural users) subscribe to MXit (World Wide Worx, 2011). Blackberry Messenger is also becoming a popular instant messaging service, particularly in South Africa, and subscribers are upgrading to these devices as soon as their cell phone contracts come up for renewal. Instant messaging seems to appeal more to teenagers than communicating via sms or email, as they enjoy real time or immediate communication, instead of having to wait for a response later on.

Other teen favourites are Facebook and Twitter. "Facebook is catching up fast reaching 22 percent of users, and in fact passing MXit in the urban over-16 market, with 30 percent reach, versus 13 percent among rural users" (World Wide Worx, 2011, para 4). Twitter will also become a key mobile tool, almost catching up to MXit in 2011, from a low 6 percent of cellular users at the end of 2010. The proportion of urban Twitter mobile users is exactly double that of rural users. i.e. 8 percent, against 4 percent (World Wide Worx, 2011).

The arrival of email in the rural user-base and its growth among urban users is remarkable. There has been a substantial shift with urban use rising from 10 percent in 2009 to 27 percent at the end of 2010. While the percentage growth among rural users is lower, the fact that it was almost nonexistent a year before means the 12 percent penetration reported for 2010 indicates mobile e-mail becoming a mainstream tool across the South African population (World Wide Worx, 2011). Lastly, 51 percent of the South African population is under the age of 25 (Walters \& Isaacs, 2009). This provides huge potential and markets for mobile devices. 


\section{Encouraging a Reading Culture}

South Africa lacks a reading culture and mobiles are starting to make a difference. The Shuttleworth Foundation's Mobile for Literacy Project, or M4Lit Project, is using cell-phones as a viable medium for the distribution of longer-form content that engages readers and gets them to participate via comments, voting, competitions and contributions. It is bridging mobile phones with books.

The fact that South African (and African) youth don't read or write enough in a traditional sense is an obvious challenge everyone's trying to fix. What's smart about the Mobile for Literacy project ... is that it doesn't push legacy or tradition. It starts with what teenagers obsess about text-based messaging - and uses this to get them to read more (Mobile books, 2010, para. 6).

Africa is a book poor but cell phone rich continent, and this has profound implications for distributing content and also for engaging with people. The success of this M4Lit Project could not only drive a new market for teen literature, but might reinvent how teen books are produced and published in Africa. The project enhances reading and writing skills in a fun way and engages teens in digital and mobile literacy. This equips them with excellent skills for university or work purposes in the future (De Waal, 2010). The M4Lit Project was the pilot phase, which then became the YOZA Project, which is a mobile library site, where new authors can share and discuss their works and get feedback from others via the YOZA mobile site. It is accessible on MXit in South Africa and Kenya (Yoza Project, n.d.).

\section{Mobile Banking and Financial Services}

Mobile phones are providing Africans with financial information and banking opportunities which never were available before. In South Africa, for instance, an estimated 13 million people - 27 percent of the population - are currently without bank accounts. At the same time, 94 percent of the adult population possesses a cell phone (Free mobile banking..., 2011). Mobile telephony has spawned mobile money in South Africa, Kenya and other parts of Africa. Many of the mainstream banks already offer mobile banking facilities. However, in bringing mobile money transfers and other banking services to those who have never entered a bank, it creates a stepping stone to formal financial services for billions of people who have never had accounts, credit or insurance (World Economic Forum, 2011). In May 2011, the Mahala Free Banking Platform was launched on cell phones in South Africa. No consumer premiums are payable, as the business model will be sustained by value-added services and advertisements (Free mobile banking..., 2011).

One problem with mobile banking is that it also gives rise to and enables criminal activity. Theft of cell phones is high in South Africa as they are being stolen for use in bank robberies, drug dealing and other crimes. Banks also have to constantly keep one step ahead of email fraud scams, like phishing, which requests clients to provide personal information for the purposes of 
information or identity theft. It is not always apparent to clients that this is in fact a scam, so banks have regular television and radio notices and messages to warn clients not to respond to such emails.

\section{Mobiles Assisting Persons with Sensory-Disabilities}

Mobile devices are also assisting visually and hearing impaired persons in South Africa and other parts of Africa, to access digital content. "The DAISY Consortium is an international association that develops, maintains and promotes international DAISY (Digital Accessible Information System) Standards" (DAISY Consortium, n.d., para. 1). This format was designed to make books accessible to those with print disabilities, as well as sighted users who simply want a standard way to take books with them wherever they go. The format allows for books to contain text, audio, or a combination of both. It also makes navigation from point to point within the book easier and more accessible compared to analogue recordings. The mobile DAISY Player supports all these formats, allowing access to the widest possible variety of electronic books. MP3 audio files can be converted to basic DAISY books (Mobile DAISY Player, n.d.,para. 1). Mobile Accessibility is a screen-access application which provides a suite of accessible applications for various uses, including touch navigation, voice synthesis, email, calendar entries, Global Positioning Systems (GPS), interaction on Facebook and other social networking (Mobile accessibility..., 2011).

The Mobile Speak screen readers have software applications installed on a mobile phone, to generate text to speech and provides Braille output at the same time as speech or independently (Introducing Mobile Speak, 2011).

More than ever before, visually impaired people have so much technology at their fingertips to help them create and take advantage of more opportunities in life. The Internet has helped visually and hearing impaired persons in so many ways, especially with their education, research, recreation and general communication with others. Since a great deal of material is now available in electronic format, blind people can obtain information for themselves quite easily, unless the format is totally inaccessible. Unfortunately there are still websites which are inaccessible or are very difficult for blind persons to access, because the needs of blind persons have not been considered in the design stage of the websites. "Despite the existence of assistive devices and accessibility guidelines, if a Web site is not designed in a manner that it is flexible enough to work with various assistive devices, there is nothing that the user can do that will lead to successful use of the site" (Lazar \& Jaeger, n.d, para. 16).

Learning materials and open educational resources are much easier to find and even online courses are open to blind and visually impaired students. Digital communication with their teachers or friends keeps them in touch and alleviates loneliness and boredom (How the Internet..., 2011). 
Talking mobile facilities now enable blind persons to communicate via sms, email and phone calls. They can participate in social networks, use navigation tools and specific map data or GPS applications to assist them in finding their way around their suburbs and environs. They can benefit from mobile banking, e-commerce, e-health, e-employment agencies and Government services (Blind Wiki, n.d.)

Visually or hearing impaired persons can use text messaging service on their phones providing they have the correct software applications enabled. Some mobile phones now have several other features which assist visually impaired persons, including voice over in thirty languages which work with all applications, typing with voiceover, support for wireless Braille displays and others features (Australian Government, n.d.).

\section{Augmented Reality in South Africa}

Augmented reality (AR) is another aspect of active digital technology which is quietly making its appearance in South Africa and is likely to make a huge difference in education, libraries and other areas of society in due course. "AR refers to the addition of a computer-assisted contextual layer of information over the real world, creating a reality that is enhanced or augmented" (New Medium Consortium, 2011, para. 2).

It can be used for visual and highly interactive forms of learning and assessment in South Africa and has the ability to respond to user input (New Medium Consortium, 2011). "Students can use it to construct new understanding based on interactions with virtual objects that bring underlying data to life. Dynamic processes, extensive datasets, and objects too large or too small to be manipulated can be brought into a student's personal space" (New Medium Consortium, 2011, para. 6) on a Smartphone or similar device, "at a scale and in a form easy to understand and work with" (New Medium Consortium, 2011, para. 6).

AR has great potential for deaf and hearing-impaired persons who need more visual or graphic descriptions to access knowledge. Even for blind persons, more descriptive information about graphics, conveyed via text to speech software, could be helpful.

\section{Increased Access to Telecommunication Services}

Mobile communications have increased access to telecommunications services particularly in developing countries, including Africa. The cellular network can be built faster than a fixed-line network, it can cover geographically challenging areas, services have been introduced in a competitive environment, and pre-paid models have opened access to mobile cellular for those who would otherwise not qualify for subscription plans. In countries, where mobile communications is the primary access to communications, increased exchange of information on trade or health services are contributing to development goals; in countries where people commonly use both fixed-line and mobile communications the personal traits of the cell phone are changing social interaction (International Telecommunication Union, 2003a, para. 3). 
There are still issues, though, that have to be resolved before cellular phones become the ideal form of communication in Africa. Some of the most popular phones, e.g. Nokia 1100 and other low end handsets do not have browsers and do not support General Packet Radio Service, or any other form of data transmission (Banks, 2008).

Network coverage in many rural areas lacks data support even if the phones have it, although this is admittedly changing. There are also issues of language and content but, more importantly, cost. Using the Web, especially if the user is not adept at searching for information, can be expensive for someone with a low phone budget (Banks, 2008).

According to the International Telecommunications Union (ITU) Report of 2009, two-thirds of the world's cell phone subscriptions are in developing nations, with the highest growth rate in Africa where a quarter of the population now has a mobile (MacInnes, 2009). This provides new options and excellent scope for information on the move in Africa.

\section{Information 'Stuck in a Groove'?}

The mobile explosion is certainly changing communication and encouraging information on the move in South Africa and on the African continent. However, information can get 'stuck in a groove', because of barriers such as restrictive legislation, licensing and technological protection measures, that are used by rights owners to control the flow of information and access to knowledge.

\section{a) Copyright as a barrier}

Copyright legislation is one of these barriers. Copyright is a "bundle" of exclusive rights that the law gives to authors and creators, to protect their original works for a certain period. Such works include literary, musical, artistic works; sound recordings; computer programs; cinematographic films, broadcasts, programme-carrying signals and published editions. The term "author" is used in a wide sense and includes composers, indexers, artists, sculptors and even architects.

Authors' rights include the right to decide whether and where their works should be published, copied, modified, digitized, broadcast, translated, performed in public, etc. Copyright is a monopoly or economic right but the author's moral rights are also protected in many copyright regimes. Copyright provides an incentive for authors to create new works and to earn some compensation for their efforts.

Copyright law provides some limitations and exceptions for users to access copyright works, but in South Africa and in the rest of Africa, these are totally inadequate. Although South Africa is a signatory to various international intellectual property agreements, it has not yet adopted appropriate legal flexibilities allowed in these agreements into its national copyright law. 
The few limitations and exceptions that the South African Copyright Act (South Africa, 1978) has are in Section 12 and 13, namely:

"Fair Dealing" (Section 12(1)) which permits copying without permission for the following purposes:

- Research or private study

- Personal or private use

- Criticism or review

- Reporting current events

Copying is also permitted in Section 12 (2-4) for quotation and by "way of illustration" in a PowerPoint presentation for teaching purposes. It is also permitted for judicial proceedings or a report of judicial proceedings. Other acts are provided for in Section 12 (4-13).

Section 13 of the Act (its Regulations) provides for limited single handouts in a classroom situation but do not extend to distance learning, informal educational programmes or staff training. There are some provisions for interlibrary loans and preservation of analogue material in libraries. However, they do not provide any exceptions for persons with sensory-disabilities, nor do they allow digitization, format shifting, uploads to digital formats, or conversions into alternative formats, for example, Braille.

In contrast to fixed-line telecommunications, intellectual property rights (IPR) for content are an essential element in mobile telecommunications. IPRs in mobile communications can be analysed with regard to exclusive rights that mobile operators acquire from content producers and licence holders, copyright protected data that mobile users can consume or download onto their mobile phones, and the potential file sharing of copyright protected mobile data over mobile peer-to-peer platforms (International Telecommunication Union, 2003b).

Copyright law hampers the process of accessing information and availability of information, particularly for educational and library purposes. If the material is under copyright, copyright clearance and payment of copyright fees are necessary before the material can be reproduced or downloaded for teaching purposes. Some universities are generating content in the form of podcasts and via e-learning tools such as Moodle which is accessible using a mobile phone. The clearance process is slow and rights holders are often unwilling to grant permission if they know the material will be loaded onto a digital platform. This even includes CDs and DVDS. 
As the use of smart phones proliferates, so too is the use of "apps" or "application software", which facilitates specific tasks for smart phone users. However, computer software is also subject to copyright protection and licensing.

Many millions of people have a disability, such as blindness or dyslexia, which prevents them from reading standard sized print. They can read the same books as their nondisabled peers, but to do so they require "accessible formats" of these books, such as large print, audio or braille. However, publishers rarely make such books, and so it is mostly left to charities to do so with scarce resources. As a result, only some five per cent of published works are ever made available in accessible formats. This is a "book famine" (World Blind Union, 2010, para.1).

Copyright laws are territorial and do not allow cross-border exchange of material in alternative formats. South Africa's copyright law has no provisions for the blind and visually impaired and limited provisions for deaf persons.

Here are two examples which show how copyright restrictions are causing the duplicate production and unnecessary extra costs for organizations and libraries servicing sensorydisabled persons:

\section{Example 1}

When Harry Potter and the Chamber of Secrets (Book 2) by J.K. Rowling was published the English speaking visually impaired organisations around the world had to produce five separate national braille master files and eight separate national DAISY audio master files. Had they been able to avoid the unnecessary use of financial and production resources for this duplication they could have produced a further four Braille titles and a further seven DAISY audio titles for sharing around the world (World Intellectual Property Organization, 2009).

\section{Example 2}

Voluntary organisations in Chile, Columbia, Mexico, Nicaragua and Uruguay have only 8,517 books in alternative formats between them. However, Argentina has 63,000 books and Spain 102,000. All these countries speak Spanish.

Imagine if reading disabled people in Argentina and Spain were able to legally share their alternative format books with their Latin American colleagues in other countries thanks to a copyright exception permitting cross-border exchanges. That would immediately and radically increase the number of readable titles for reading disabled people in the five countries mentioned above (World Blind Union, 2010).

Copyright legislation is therefore creating a huge accessibility problem for blind and visually impaired persons around the world. The World Blind Union, supported by a 
number of South American countries, proposed a Treaty at the World Intellectual Property Organization in Geneva, for Blind, Visually Impaired and Reading Disabled Persons. There have been hot debates and discussions about this Treaty for a few years now. The United States, the European Union and the African Group also submitted alternative proposals which have now been consolidated for discussion at the WIPO General Assembly during 2011.

\section{b) Licensing}

Since digital material is so easy to duplicate and distribute, rights-holders have sought to protect their digital material in a variety of measures, in addition to copyright law.

Restrictive licences, publisher conditions and digital rights management with technological protection measures are now being used as extra precautionary measures to ensure their digital content stays intact and is paid for accordingly. Some measures are more insidious than others, but all create barriers to accessing information.

Licences have become a core part of intellectual property rights management in the digital environment. Licences allow the copyright holder to devolve specific rights to use, store, copy and disseminate work to a third party, whilst maintaining control at all times. Licences are typically restrictive, and acceptable uses of the licensed work are carefully delineated, often overriding existing copyright exceptions (UKOLN, n.d.).

Whether the material is licensed before loading onto a mobile device or whether the mobile phone can only accept licensed material, access to information is restricted in the process. Only applications linked to certain mobile devices will accept information on to the device. As of early 2011, there were more than 300,000 apps just for the iPhone and more than 200,000 available through the Android Market. These numbers have already increased considerably, yet iPhone users can only use apps from the Apple Store. Other platforms can download apps from any website.

There are various types of apps, including educational apps, but if users in developing countries cannot go online easily, due to accessibility and affordability problems, then apps are of limited use to them (Commonwealth of Learning, 2011).

Bulk licensing to educational institutions for mobile content, for instance, is not available at this stage. This means that institutions have to adopt an ad hoc approach to software provision on mobile devices (Patterson, 2011).

\section{c) Digital Rights Management}

Digital Rights Management (DRM), or ...electronic copyright management systems, are technologies designed to automatically manage rights in relation to information. This can include preventing copyright works and other information from being accessed or copied 
without authorization and establishing and enforcing license terms with individuals. DRM systems comprise a number of technological components, which can include encryption, a surveillance mechanism, databases of works, owners and users, license management functionality and technological protection measures (TPMs) (University of Ottawa, 2011).

DRM is a form of continual protection that protects works and manages rights at all times, no matter where the works are located or who has possession of them. The rights owner essentially locks the user into their product or digital content. DRM attempts to promote authorized use of a copyright work, in part by precluding the possibility of copyright infringement. While DRM systems provide many advantages to information providers they can place users at a disadvantage. Legitimate users of a site may find themselves limited by conditions imposed on them by the providers. For example, files may be "Read Only", so users cannot copy small parts of the text in order to quote the work. They may also find that they can only access the software from a certain machine; they may not be able to copy it from desktop computers to more convenient laptops (Knight, 2004). DRMs cannot distinguish between infringing and legitimate usage, and block all users. In fact, hackers or "pirates" can circumvent these technologies quite easily, so the ones that are really affected negatively are legitimate users, including persons with sensory disabilities, researchers, librarians and educators.

Because of the limited access afforded by DRM, it has the potential to protect a work indefinitely. DRMs can remain embedded in digital formats long after the copyright term has expired, making content inaccessible when it should be in the public domain. This permanent lock-down of the public domain runs contrary to the principle of balancing the interests of creators and of the public in copyright law. Similarly, DRM also threatens access to many works over the long-term because data stored in proprietary DRM formats (whether it be songs, software, electronic books or other data) are at much greater risk of being lost once the playback media is no longer available, locking away the protected data forever (University of Ottawa, 2011).

Digital technology has the potential to revolutionize the lives of people with sensorydisabilities, but DRMs create access barriers. For example, text-to-speech synthesizers allow words on the screen to be read out aloud and images to be described verbally. This enables the blind person to hear, rather than read, the text. There is also software that enables a computer to react to voice commands instead of those rendered via a keyboard or mouse. There are screen readers that translate electronic text into Braille. However, publishers of e-content often apply DRM that makes it incompatible with compensatory technology like screen readers. Adobe and Microsoft build DRM technology into their ebook software that allows publishers to disable text to speech capability, making the content useless to visually impaired readers (Kramer, 2007). 
There are also other obstacles for visually impaired persons, which take many forms. A common one is the Captcha, a security feature consisting of a string of distorted letters and numbers that users are supposed to read and retype before they register for a new service or send e-mail. Few websites offer audio Captchas. Some pages are poorly designed, like e-commerce sites where the "checkout" button is an image that is not labelled so screen readers cannot find it (Helft, 2009).

Overly restrictive DRM is a challenging issue for libraries because it narrows users' rights to access and manipulate legally acquired content. Libraries sometimes agree to pay-per-use licensing models or accept end-user licensing agreements, so that they can distribute content to mobile users. DRMs can prevent preservation, archiving, and other exceptions allowed in copyright law. They prescribe and control how users can access and use digital content by overriding copyright exceptions and creating technological barriers where no legal barriers exist. The ability of sensory-disabled persons to benefit from digital media is therefore being undermined by DRMs (Nicholson, 2006).

International IP agreements and national laws in some countries prohibit users from circumventing or bypassing these protection measures for legitimate access purposes. South Africa's Copyright law does not address anti-circumvention measures, but they are provided for in the Electronic Communications and Transactions Act No. 25 of 2002 (Nicholson, 2006).

\section{d) Digital Rights Management and Copyright Law}

International Treaties, such as the WIPO Copyright Treaty ${ }^{4}$ and the WIPO Performances and Phonograms Treaty ${ }^{5}$, support DRMs in national copyright legislation.

DRMs allow companies and other creators to reserve rights for themselves which they do not legally have. For example, under copyright law in most countries, one has the right to use excerpts of copyright material (such as music, books, films etc.) for the purpose of review. However, when those works are protected by DRM, a third party (such as the creator of that material) can prevent one from exercising those rights (Jackson, 2003, para. 14).

In fact, in trying to exercise these rights, one could be breaking another law, for example, the Electronic Communications and Transactions Act in South Africa, or the Digital Millennium Copyright Act (DMCA) in the United States. DRMs have therefore succeeded in imposing their own personal control laws, which supersede national copyright laws, which are generally more favourable to rights holders than consumers of information (Jackson, 2003).

${ }^{4}$ http://www.wipo.int/treaties/en/ip/wct/index.html

${ }^{5}$ http://www.wipo.int/treaties/en/ip/wppt/index.html 


\section{e) E-Books for Libraries}

DRMs and licensing have obvious implications for the future of e-Books. Are digital formats really persistent and perpetual? What is the life expectancy of an e-book? These are serious concerns for libraries and their users.

Many assume that the e-book is a replacement for the physical or hard copy of the book. The distinct difference between a physical book on the shelf and an e-book on a server is that the former is likely to be there for a very long time, whilst the e-book may not be accessible in a very short time (Daniels, 2011).

Some academic libraries in South Africa have decided to stop buying print books if they are available in electronic form. Is this a wise decision at this stage? Libraries may have a reasonable process for preserving digital content, but this will not be possible if publishers follow the recent decision of HarperColllins, which has angered librarians around the world. Some library consortia in the United States have decided to forgo the purchase of HarperCollins e-book titles in the wake of the publisher's decision to set a license limit of twenty-six checkouts per title and also amid concerns about what may be next (Kelley, 2011).

HarperCollins Publishers have given a whole new meaning to "Library Short Loans". Their e-book licences currently only allow twenty-six library loans or checkouts before the e-book "implodes" itself and can no longer be accessed until a new license is purchased. This contradicts every library's statutory mandate to provide reasonable access to their collections. It also goes against their collection development policies and service excellence promises, as they cannot offer long-term use of any of these e-books. We tend to assume that all books (print or electronic) once purchased are ours for life and that we can read, lend and share with any reader. HarperCollins will halt that sharing culture and transfer of knowledge unless they reverse their draconian licence decisions. They are dictating to libraries how their collections must be used and for how long. Ebooks will become like temporary loans from publishers to libraries at a price. This is unacceptable to librarians and readers. Large publishers like Macmillan and Simon \& Schuster in the United States do not allow any library circulation of their books (Hadro, 2011).

Amazon has recently taken the decision to allow Kindle e-books for library use, but the Kindle service will only be available in the US, just like the e-book sharing, apps, or any other Kindle extras. Overdrive, the service provider, is more than capable of providing the service around the world, but Amazon refuses to allow this (Hoffelder, 2011).

What about the developing world? Are e-books going to be a privilege reserved for affluent countries?

\section{f) e-Books for Individuals}


Some DRMs lock customers into using a single content distribution service. Many providers that implement DRM on the content they distribute do so to keep customers returning to their online stores. Some content legally purchased from online e-book stores is locked into a specific format that can be read only on devices sanctioned by the provider (Vollmer, 2010). Individual users of e-books may find that their books have a short shelf life, as the DRM may restrict access after a certain period or may continue locking up content long after the copyright term has expired. Individuals also may not have the finances or technical ability to keep upgrading the software or to migrate it to new technology as old ones become obsolete.

New formats evolve all the time, but not all versions will remain retrospectively compatible. In other words, older e-formats may not be accessible within a few years, unless the software is upgraded on a regular basis and/or the licence has adequate flexibility to facilitate, rather than restrict access to the digital content (Daniels, 2011).

Ironically, authors refusing to make their works available in digital form are finding they are being pirated anyway. J.K. Rowling, for instance, refused to publish her Harry Potter books digitally. As a result her books are among the most pirated titles year after year. Every single book from the Harry Potter series is available digitally, either scanned or transcribed by fans (Publishers fear ebooks..., 2010).

\section{g) Remotely Wiping Mobile Phones}

Another area where digital content is at risk is the use of remote wiping of mobile data. The mobile phone is increasingly becoming as functional as a personal computer, which means it is commonly being used to store more inviting data for criminal activity, consequently making it more susceptible to theft. The modern mobile phone is likely to contain sensitive information, passwords, personal documents and access to its user's entire social network, a worrying amount of information to lose or fall into the wrong hands (BullGuard, 2011).

Many of the modern smartphones have remote wipe features, which enable users to remotely erase all data on their phones, if the need arises for legitimate purposes. However, there is a negative side to this as well. The remote wipes available for Android iPOs and Palm's webOS allow exchange administrators or an employer to remotely reset logged in mobile phones, removing all personal data and resetting them to factory defaults. Some are using this as a way of disciplining employees who log into servers from unapproved devices. Others have erased data in error because their staff member's phone was configured to receive email from their Microsoft Exchange Server, the kind most big companies use. Therefore, if an employee is linked to the said server, he/she must ensure that there is automatic backup, otherwise all his/her data could be wiped clean from his mobile phone (Kaste, 2010). The danger of this is that this power could be 
abused. Additionally, incriminating evidence could disappear by remote wipe if criminals know how to use the features. Mobile phones are being used in criminal activity, for example, bank robberies and organized crime, even illegally in prisons, and this is a worry for crime fighting agencies.

\section{Role of Libraries Regarding Access Barriers}

DRMs, unfortunately, are already here and most mobile devices and computers probably have DRM-enabled applications on them already (even though we may not be aware of them).

A significant part of our role as librarians is to serve as advocates for unhindered access to information for our users, who include publishers, authors, software programmers, educators, learners and other people from all walks of life (Puckett, 2010). Throughout history, librarians have been called upon to combat censorship over the flow of information. Today, censorship comes under the guise of licences, digital rights management and restrictive copyright laws, which affect access and fair use or fair dealing, in ways that are unprecedented in the modern era. (Why should open..., n.d.) . When we do nothing to protest unreasonable licensing conditions or DRM restrictions, we implicitly give our consent (Puckett, 2010). If we are not advocating open, freely usable digital content for our users, can we really call ourselves librarians? We must "advocate for open, freely usable digital content" (Puckett, 2010, p. 23).

There are some things librarians can do to stop restrictive licences and the proliferation of DRMs on e-books and other digital content. They can negotiate better licences with e-publishers and refuse to sign standard licences with reduced rights for their users. Libraries should be encouraged not to buy or install DRM-enabled software. When ordering books, music, films, ebooks and other digital content, they should first check if it is DRM-protected. If it is DRMprotected, they should insist that the DRM be removed before the item is purchased, alternatively that the digital work be supplied in an open format that gives users the freedom to use it in a way that suits them. Librarians need to ensure that all their users can have access to this work, not just individuals with separate password protection. Librarians should make it clear to publishers and providers that DRMs are not acceptable for library collections and unless accessible to all their users, they cannot purchase the digital item or content. They should insist that publishers' blurbs, advertisements and online information clearly indicate which items are DRM-protected.

Libraries should not be pressured into accepting DRM-protected material. After all, they are key customers and their needs should be respected by publishers and providers of digital content (Jackson, 2003).

\section{Conclusion}

Mobile technologies, particularly mobile phones, have a major role to play in libraries, education and other aspects of modern life in South Africa and on the African continent. Copyright laws 
need to be appropriately amended to address the digital environment in the context of developing and least developed countries in Africa. The benefits of Open Access publishing and open source licensing should be promoted as widely as possible, to ensure easy access and free flow of information.

For Africans, it is not the smartest or latest mobile gadgets like Kindle or iPad that will make a difference. It is the smart ideas that work with existing devices and the promotion and proliferation of open content that will change their lives for the better (De Waal, 2011).

In addition, "[the] tipping point for African research" (Southern African Regional Universities Association [SARUA], 2008, p. 7), innovation and development "will not be merely the ability to fully access and use the new abundance of global knowledge and ideas, but to make an active and significant contribution to its creation"(SARUA, , 2008, p.7).

\section{References}

At 27 Million MXit is Africa's largest social network. (2010). Retrieved from http://www.webaddict.co.za/2010/10/22/mxit-africa-largest-social-network/

Australian Government. Job Access. (n.d.). Mobile phones for the blind or vision impaired. Retrieved from http://jobaccess.gov.au/Advice/ProductOrSolutionOne/Pages/mobile\%20phones\%20for\%20the \%20blind\%20or\%20vision\%20impaired.aspx

Banks, K. (2008). Mobile Phones and the Digital Divide. Retrieved from http://www.pcworld.com/article/149075/mobile_phones_and_the_digital_divide.html

Blind Wiki. (n.d.). Open Letter Initiative. Retrieved from http://blind.wikia.com/wiki/Open_Letter_Initiative\#Mobile_technology_is_a_revolutionary_cha nce_for_blind_people

BullGuard. (2011). Track, lock and wipe your mobile phone. BullGuard's Antitheft feature makes it possible to remotely control your smartphone Mobile Security. Retrieved from de http://www.bullguard.com/news/latest-press-releases/press-release-archive/2011-03-30.aspx

Commonwealth of Learning. (2011). All about Apps. EDTECH News, Feb. 2011. Retrieved from http://www.col.org/news/Connections/2011feb/Pages/EdTech.aspx

DAISY Consortium. (n.d.). About us. Retrieved from http://www.daisy.org/about_us

Daniels, M. (2011.). Are e-Books being straight-jacketed by pbook thinking? Brave New World. Retrieved from http://bookseller-association.blogspot.com/2011/03/are-ebooks-being-straightjacketed-by.html 
De Waal, M. (2010). Mobile books the South African way. The Daily Maverick, 8 July 2011. Retrieved from http://www.thedailymaverick.co.za/article/2010-07-08-mobile-books-the-southafrican-way

E-Voting in Africa: Mr. Collin Thakur: Interviews. PCTech, 7, Sept/Oct 2010. Retrieved from http://ctbus.files.wordpress.com/2010/10/issue7extracts.pdf

FreedomFone. Retrieved from http://freedomfone.org

Free mobile banking network launched in South Africa. (2011). Retrieved from http://www.springwise.com/financial_services/mahalaproject/

FrontlineSMS (n.d.). Retrieved from http://www.frontlinesms.com

Gray, E. (2010). Gray Area. About this blog. Retrieved from http://www.grayarea.co.za/category/open-education

Hadro, J. (2011). HarperCollins Puts 26 Loan Cap on Ebook Circulations. Library Journal.com. Retrieved from http://www.libraryjournal.com/lj/home/889452-

264/harpercollins_caps_loans_on_ebook.html.csp

Helft, M. (2009). For the Blind, Technology Does What a Guide Dog Can't. StarNews Online. Retrieved from

http://www.starnewsonline.com/article/20090104/ZNYT01/901043004?p=3\&tc=pg

Hoffelder, N. (2011). Kindle Library eBooks Limited to Only US Libraries. Retrieved from http://www.mediabistro.com/ebooknewser/kindle-library-ebooks-limited-to-only-uslibraries_b9361

How the Internet Has Helped the Blind in Education. (2011). Retrieved from http://www.academicresources.net/how-the-internet-has-helped-the-blind-in-education.htm International Telecommunication Union.. (2003a). Mobile overtakes fixed: implications for policy and regulation. Retrieved from http://www.itu.int/osg/spu/ni/mobileovertakes/Resources/Mobileovertakes_Paper.pdf

International Telecommunication Union. (2003b). What do we mean by "mobile overtakes fixed?" Retrieved from http://www.itu.int/osg/spu/ni/mobileovertakes/index.htm

Internet Users in the World Distribution by Region. (2011). Retrieved from http://www.internetworldstats.com/stats.htm

Introducing Mobile Speak. (2011. Retrieved from http://www.codefactory.es/en/products.asp?id=316\#Whatsc 
Jackson, T. (2003). The fallacy of DRM. Retrieved from http://www.timj.co.uk/computing/politics-policy/drm/fallacy

Kaste, M. (2010). Wipeout: When Your Company Kills Your iPhone. Retrieved from http://www.npr.org/2010/11/22/131511381/wipeout-when-your-company-kills-your-iphone

Kelley, M. (2011). Library consortia begin to vote against HarperCollins Ebook checkout policy. Retrieved from http://www.libraryjournal.com/lj/home/889582264/library_consortia_begin_to_vote.html.csp

Knight, A. (2004). Internet publishing and digital rights: the changing balance between access and ownership. Retrieved from http://www.csa.com/discoveryguides/internet/overview.php

Kramer, E.F. (2007). Digital rights management: pitfalls and possibilities for people with disabilities. Journal of Electronic Publishing. 10(1), Winter 2007. Retrieved from http://quod.lib.umich.edu/j/jep/3336451.0010.106?rgn=main;view=fulltext

Lazar, J. and Jaeger, P. (n.d.). Reducing Barriers to Online Access for People with Disabilities. Retrieved from http://www.issues.org/27.2/lazar.html

MacInnis, L. (2009). Mobile phone growth helps poorer states: U.N. Retrieved from http://www.reuters.com/article/2009/03/02/us-technology-un-idUSTRE5211GJ20090302

Massive Undersea Cable Connects Africa (2011). Retrieved from http://news.discovery.com/tech/internet-undersea-cable-africa-110407.html

Mobile accessibility and other accessible Android apps. (2011). Retrieved from http://www.codefactory.es/en/products.asp?id=415

Mobile books the South African way. (2010). Retrieved from http://www.thedailymaverick.co.za/article/2010-07-08-mobile-books-the-south-african-way Mobile DAISY Player. (n.d.). Retrieved from http://www.adaptivetr.com/mobile-daisy-player Mobile phones and development: the basic facts. [Draft]. Retrieved from www.wsiscommunity.org/mod/file/download.php?file_guid=244736New Medium Consortium. (2011). Nicholson, D.R. (2006). Are people with sensory-disabilities getting a fair deal? Retrieved from http://pcf4.dec.uwi.edu/viewabstract.php?id=379

Okine, C.B. (2011). MTN To Expand Internet Frontiers, Retrieved from http://www.graphic.com.gh/business/page.php?news=12506

Patterson, W. (2011). Personal email communication with Denise Nicholson. 
Publishers fear ebooks piracy, but shouldn't. (2010). Retrieved from

http://torrentfreak.com/publishers-fear-ebook-piracy-but-shouldnt-100103/

Pringle, A. (2011, February). Mobiles and Community Radio: Together at last.

Connections/EdTech News. Retrieved from

http://www.col.org/news/Connections/2011feb/Pages/default.aspx

Puckett, J. (2010). Digital Rights Management as information access barrier. Retrieved from http://digitalarchive.gsu.edu/cgi/viewcontent.cgi?article=1049\&context=univ_lib_facpub

South Africa (1978). Copyright Act No. 98 of 1978 (as amended).

Southern African Regional Universities Association (SARUA). (2008). Opening Access to

Knowledge in Southern African universities. SARUA Study Series, 2008. Retrieved from

http://www.sarua.org/files/publications/OpeningAccess/Opening_Access_Knowledge_2008.pdf

The Master of $I M$, (n.d.). Retrieved from http://www.itheroes.org.za/?m=6\&idkey=67727

Two to three years: Augmented reality. 2011 Horizon Report. Retrieved from

http://wp.nmc.org/horizon2011/sections/augmented-reality/

UKOLN. (n.d.). Choosing Alternative Licences For Digital Content: A QA Focus Document. Retrieved from http://www.ukoln.ac.uk/qa-focus/documents/briefings/briefing-54/briefing-54$\underline{\text { A4.doc }}$

University of Ottawa. Canadian Internet Policy and Public Interest Clinic. (2011). Digital Rights Management. Retrieved from http://www.cippic.ca/digital-rights-management/

Vollmer, T. (2010). There's an App for that libraries and mobile technology: an introduction to public policy considerations. ALA Office for Information Technology Policy. Policy Brief. No. 3, June 2010. Retrieved from http://www.scribd.com/doc/32916970/There-s-An-App-For-ThatLibraries-and-Mobile-Technology-An-Introduction-to-Public-Policy-Considerations

Walters, S \& Isaacs, S. (2009). National Qualifications Framework: Insights from South Africa. Retrieved from http://www.saqa.org.za/docs/events/2009/eqf_paper.pdf

Wanjiku, R. (2011). Africa banking on mobile to be first post-PC continent. Retrieved from http://www.computerworlduganda.com/articles/2011/04/05/africa-banking-mobile-be-first-postpc-continent

Watters, A. (2011). Mobile phones, educational apps, and the digital divide. Retrieved from http://www.hackeducationcom/2011/02/17/mobile-phones-educational-apps-and-the-digitaldivide/Mobile 
Why should open source software be used in schools. (n.d.). Retrieved from http://edgeop.org/grouch/schools.html

World Blind Union. Committee on the Rights of Persons with Disabilities Day of General Discussion on "The Right to Accessibility". (2010). Paper by the World Blind Union on a WIPO Treaty for Improved Access for Blind, Visually Impaired and other Reading Disabled Persons Executive summary. Retrieved from http://www2.ohchr.org/SPdocs/CRPD/DGD7102010/submissions/WBU_II.doc

World Economic Forum. (2011). The global Information technology report 2010-2011. Retrieved from http://www3.weforum.org/docs/WEF_GITR_Report_2011.pdf

World Intellectual Property Organization. (2009). Presentation by Mr. Christopher Friend.

Retrieved from http://www.wipo.int/meetings/en/2009/vip_ge/presentations/chris_friend.html

World Wide Worx. (2011). SA cellphone users embrace Internet. Retrieved from http://www.worldwideworx.com/2011/02/03/sa-cellphone-users-embrace-internet/

Yoza Project. (n.d.). About the project. Retrieved from http://yozaproject.com/about-the-project/ 